\title{
Cancer drug resistance: rationale for drug delivery systems and targeted inhibition of HSP90 family proteins
}

\author{
Clélia Mathieu1, Samir Messaoudi², Elias Fattal', Juliette Vergnaud-Gauduchon' \\ 'Institut Galien Paris-Sud, CNRS, UMR 8612, Université Paris-Sud/Paris-Saclay, Châtenay-Malabry 92296, France. \\ ${ }^{2}$ BioCIS, CNRS, UMR 8076, Université Paris-Sud/Paris-Saclay, Châtenay-Malabry 92296, France.
}

Correspondence to: Dr. Juliette Vergnaud-Gauduchon, Institut Galien Paris-Sud, CNRS, UMR 8612, Université Paris-Sud/ParisSaclay, Châtenay-Malabry 92296, France. E-mail: juliette.vergnaud@u-psud.fr

How to cite this article: Mathieu C, Messaoudi S, Fattal E, Vergnaud-Gauduchon J. Cancer drug resistance: rationale for drug delivery systems and targeted inhibition of HSP90 family proteins. Cancer Drug Resist 2019;2:381-98.

http://dx.doi.org/10.20517/cdr.2019.26

Received: 7 Apr 2019 First Decision: 13 May 2019 Revised: 24 May 2019 Accepted: 3 Jun 2019 Published: 19 Sep 2019

Science Editor: Helen M. Coley Copy Editor: Cai-Hong Wang Production Editor: Jing Yu

\begin{abstract}
Nanocarriers have been developed in order to protect drugs or to improve drugs efficiency by reaching the damaged tissue and avoiding systemic and local toxicity. By using HSP9O inhibitors, some cancer drug resistances have been overcome and the loading into nanocarriers of such drugs has shown an increase of their activities. This review will present some advantages of HSP9O inhibitors to treat resistant tumors; especially those targeting the mitochondrial protein TRAP1. We will also focus on the targeting of the primary tumors, cancer stem cells and metastatic cells.
\end{abstract}

Keywords: Heat-shock proteins, cancer, resistance, nanoparticles

\section{INTRODUCTION}

According to the World Health Organization, 9.6 million of death are imputed to cancers in 2018. Despite lots of progress in cancer therapy, there are still lots of relapses and resistant cancers. In spite of a large scope of targets for anti-cancer drugs, the use of inhibitors and drugs may lead to development of resistances. The study of the drug resistance mechanisms allowed the development of new drugs which are more efficient and thus is a promising scope of study to improve oncologic treatments. Some cancers developed resistance to multiple drugs, and it is primordial to find how to reverse this mechanism. Even if new strategies are

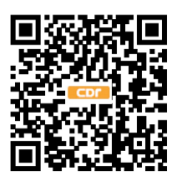


promising a large panel of researches focus on the development of drug delivery systems. This review will combine the rationale to use nanocarriers to improve the efficiency of anticancer drugs with the role of Heat Shock Proteins (HSP) in the drug resistance and how inhibition of specific isoforms is a promising strategy to sensitize cancer cells to death.

\section{DRUG DELIVERY SYSTEMS, THE WAY TO OVERCOME CANCER RESISTANCE TO THERAPY}

As drug resistance is not only due to genetic alterations, several hallmarks have been identified to represent mechanisms of resistance: overexpression of drug efflux pumps [P-glycoprotein (P-gp)], activation of proproliferative and/or prosurvival (antiapoptotic) pathways, metabolic changes which confer to heterogeneous cancer cell populations differential dependency to glucose and to biosynthetic blocks and finally modulation of tumor microenvironment (inflammatory, immune cells and fibroblasts) ${ }^{[1,2]}$. Some of these mechanisms affect cancer stem cells which have plasticity properties and which are responsible for the maintenance of tumors despite treatment and induce poor clinical outcome for patients ${ }^{[3]}$.

A major point which in part explains the low efficacy of conventional or targeted therapies to fight cancer cells is the compensatory mechanism that is used by these cells displaying redundancy between pathways. For example, even if one signaling molecule is inhibited by therapy, another one involved in a secondary pathway or being downstream of the first one activates a similar cellular program which confers proliferative properties $^{[1]}$. Then, strategies have to focus on multiple pathways to increase chances to be effective with treatment. A family of proteins has been identified as a controller of signaling pathways: The Heat Shock Proteins. They are implicated in many physiological processes by preventing mis(un-)folding, denaturation of proteins. In cancer cells, these functions are associated with stabilized pro-tumoral protein like growth factor receptors, transcription factors, ... The HSP family will be more deeply described in the last part of this review by focusing on HSP targeting. Nevertheless, two decades ago first evidences appeared in relation to the involvement of HSP in resistance mechanisms. As the HSPs are induced in vitro by cytotoxic drugs, it has been hypothesized that HSP would play an important role in the tumor cell tolerance. For example, in 1998, Vargas-Roig et al. ${ }^{[4]}$ published a breast cancer patient-based study showing a correlation between a high nuclear level of HSP70 in tumor cells and drug resistance. The combination of HSP27 and HSP70 correlated strongly with the disease-free survival of patients ${ }^{[4]}$. More recently, a review has summarized the importance of HSP in the chemoresistance of ovarian cancer ${ }^{[5]}$. It has been demonstrated that treatment of ovarian cancer cells induced HSP27, HSP70 and HSP90 as well as HSP60 and TNF receptor-associated protein 1 (TRAP-1) and the use of HSP inhibitors was shown to be active against the growth of resistant tumors. Nevertheless the authors of this review concluded that strategy using HSP inhibition has to be chosen patient by patient ${ }^{[5]}$. The transcription factor heat shock factor 1 (HSF-1) activates the transcription of HSP genes and has been associated to resistance mechanisms. Particularly, mammary tumorigenesis displays a link between HSF-1 and ERBB2 the Human epidermal growth factor receptor 2 (HER2). ERBB2 has been identified as a client protein of HSP90 machinery and in lapatinib-resistant ERBB2-positive breast cancer cells HSF1-mediated heat shock pathway is responsible for the adaptation of the receptor tyrosine kinase kinome of cancer cells. Interestingly these cells are sensitive to inhibition of HSF-1 and HSP90 confirming the therapeutic potential of the targeting HSP system ${ }^{[6]}$.

Besides the potential role of HSP inhibition in overcoming the multidrug resistances, some groups focused their research on the development of strategies involving combination therapies, inhibition of the drug efflux pumps, and of $\mathrm{ABC}$ cassettes ${ }^{[7-9]}$. Combination therapies are more and more developed as standard of care for resistant cancers: that includes RVD [Lenalidomide (immunomodulatory drug), Bortezomib (proteasome inhibitor), Dexamethasone (glucocorticoid)] for relapsed multiple myeloma, Cyclophosphamide, Adriamycin and fluorouracil (CAF) for metastatic breast cancer or Bleomycin, etoposide phosphate, cisplatin (BEP) for ovarian malignant cancer, ... Several principles must be considered while setting up a strategy for combination 


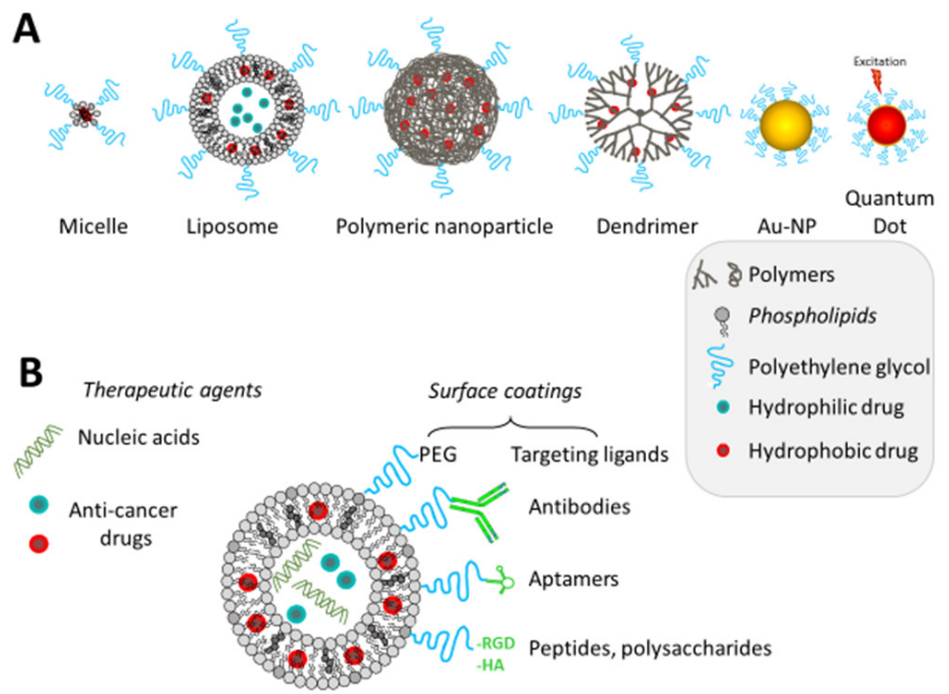

Figure 1. Main types and composition of nanocarriers used for cancer treatment and/or imaging (A); how can the nanocarrier be modified to target cancer cells (B)

therapies ${ }^{[10]}$. There must be no overlapping toxicities of the drugs used, their mechanisms of action must be clearly different, and there must be a minimal cross resistance. Drug solubility and permeation should also be similar in order to allow a good delivery and high intracellular levels. Eventually, the dose/ratios should be optimized in order to reach a synergetic effect between the different drugs. These last two conditions make very complex the design of combination therapies with different drugs. Furthermore, even if the overlapping toxicities are minimum, administration of several drugs at the same time ("cocktail administration") induces high toxicity to normal tissue. To avoid that, the drugs can be administered sequentially which is not optimum for the patient ${ }^{[1]}$. The combination of different drugs within one nanocarrier might help solving these issues.

Indeed, in the past few years, nanoparticles have become an interesting platform for medicine and treatment of cancers. They have several properties interesting for diagnosis and therapy [Figure 1]. First, they are multifunctional, so they can combine both diagnosis and therapy and though be used for personalized treatments or theranostic. Furthermore, they can have various structures, shapes and sizes. By modulating these parameters, an enhanced permeability and retention (EPR) effect can be observed: nanoparticles naturally accumulate into tumors due to the fenestrated neoendothelium and the low lymph drain in tumor tissue $^{[12]}$. However, this effect is limited by the poor tumoral blood stream, the tumor type, the high tumor interstitial fluid pressure and the heterogeneity of the vascularization. Nevertheless, there are several methods to improve nanoparticles uptake by tumoral cells, and the efficacy against resistant cancers. Nanoparticles allow the protection of fragile molecules and help to have a controlled released in the target tissue.

\section{Improving nanoparticles tumor accumulation and selectivity by active targeting}

One of the strategies to improve nanoparticles uptake by cells includes the use of active targeting. It involves a ligand specific of a cell-surface receptor linked to the nanoparticle ${ }^{[13]}$. This ligand can be a protein, a peptide, an aptamer, a natural binder or a small molecule. Lots of biomarkers has been studied and are interesting to target, like the markers of angiogenesis (integrins, NRPs, ... $)^{[14]}$, or some proteins expressed on the surface of cancerous cells $\left(\mathrm{BCMA}^{[15]}, \mathrm{Mucl}^{[16]}, \ldots\right)$. Recently, in numerous resistant cancers including pancreatic, breast, ovarian, prostate, colorectal cancers and neuroblastomas; CD44 has been identified as an interesting marker of cancer stem cell like cells. Yet, CD44 is involved in tumor progression, metastasis, drug resistance and its expression has been correlated to disease prognosis ${ }^{[17]}$. So researchers have been interested 
by targeting it, and developed different strategies to do $\mathrm{so}^{[18]}$. One of them is to use hyaluronic acid (HA), a natural agonist of $\mathrm{CD} 44$. It is a critical component of the extracellular matrix and it is degraded through enzymatic reactions ${ }^{[19]}$. So, it is bio-compatible. It has been used for surface modification of a nanoparticle, for instance Sun et al. ${ }^{[20]}$ designed a positively charged liposome, encapsulating a combination therapy composed by synergistic amount of NF- $\mathrm{\kappa B}$ and STAT3 inhibitors (curcumin, celecoxib and a dual peptide TAT-NBD) for the therapy of metastatic inflammatory breast cancer. Thanks to the positive charges at the surface of the liposome, they coated it with HA which is negatively charged. They showed that the drug release was enhanced by hyaluronidase (HAase) and that the uptake was selective toward CD-44 expressing cells (in vitro and in vivo). Our lab developed several types of lipid based nanocarriers to target CD44positive tumor cells using HA as a ligand and to deliver anticancer drugs or siRNA (for original research and reviews see $\left.{ }^{[21-24]}\right)$.

HA can also be used for self-assembled nanoparticles. Indeed, the conjugation of hydrophobic, or positively charged, moieties with hydrophilic, or negatively charged respectively, parts results in selfassembled nanoparticles ${ }^{[20]}$. For example Lee and Cho has grafted a hydrophobic analog of vitamin E (D- $\alpha-$ tocophenol succinate) to HA in order to give self-assembled nanostructures ${ }^{[25]}$. Moreover, they also grafted triphenylphosphonium moiety (cationic and lipophilic) to HA in order to add a mitochondrial targeting. In this nanostructure, they encapsulated lapatinib, a dual tyrosine kinase inhibitor of EGFR and HER2 ${ }^{[26]}$. The targeting capacity of this system was demonstrated in an in vivo model of triple negative breast cancer. However, there are a receptor for endocytosis present in lung and liver which are responsible for early clearance of $\mathrm{HA}^{[18]}$. Chondroitin sulfate is another natural compound that has been reported to have a specificity for CD44 receptors. Thus, Zhang et al. ${ }^{[27]}$ used it to synthesized nanogels with a good affinity for CD44 receptors. They prepared a paclitaxel-chondroitin sulfate conjugates cross-linked with a glutathione (GSH) sensitive disulfide bridge to form the nanogel and loaded free paclitaxel and free sunitinib in synergistic ratios. Thanks to the GSH contained in cells the chondroitine sulfate conjugate will be degraded to allow release of drugs. First, they showed that the more tumor cells expressed CD44 receptors, the more the nanogel was internalized. Finally, they show a first burst release of the free drugs, once the nanogel internalized, and a sustained paclitaxel released from the conjugated drug. This system was set up to overcome drug efflux pomp resistance. The use of antibodies is also an excellent approach for targeted delivery. To target $\mathrm{CD} 44$, Lu et al ${ }^{[28]}$ conjugated an anti CD44 antibody to a liposome through a thiol-maleimide reaction. They encapsulated a steroin saponin TAIII, a hydrophobic antitumoral drug candidate. They demonstrated that this encapsulation improved the solubility and the bioavailability of the drug. Furthermore, they showed the tumor accumulation thanks to the CD44 targeting: an improved in vitro uptake of HepG2 cells was observed by fluorescence of the targeted liposome compare to the unconjugated one. They also showed a greater accumulation of these liposomes in tumoral site in HepG2 xenograft mice. However, an antibody is a large protein with only a small specific fragment. Another strategy is to conjugate only the specific fragment in order not to change the behavior of the nanoparticles. Another group chose to re-engineer the Fab fragment of a human anti-CD44v6 antibody by adding 3 more cysteine. This allow them to conjugate it with a maleimide-nanoparticle to have a better binding affinity ${ }^{[29]}$. The fragment they used had an affinity of 2-6 $\mathrm{nmol} / \mathrm{L}$ for $\mathrm{CD} 44 \mathrm{v} 6$ and $6-70 \mathrm{nmol} / \mathrm{L}$ for the other proteins of the family. After re-engineering, the affinity was of 10-90 nmol/L, then they validated the affinity after conjugation with the nanoparticle. With the same type of conjugation (thiol-maleimide) the targeting of CD44 has been done in our group using an aptamer ${ }^{[30,31]}$. The free anti-CD44 RNA-based aptamer has a binding affinity around $21 \mathrm{nmol} / \mathrm{L}$, whereas the liposome conjugated to the aptamer has an affinity of $6 \mathrm{nmol} / \mathrm{L}^{[32,33]}$. This can be explained by multivalent binding of the liposomes to CD44. Another system used a layer of chitosan, a polysaccharide biocompatible and biodegradable, to target $\mathrm{CD} 44^{[34]}$. They developed a multilayer system, allowing to deliver 3 drugs in the same time (doxorubicin, paclitaxel and silybin) for the treatment of drug-resistant breast cancer. 


\section{Nanoparticles to improve the delivery for combinations of therapies}

Nanocarriers are useful for drug delivery system, and therefore for combination of drugs. First, they can overcome drug-solubility problems by conjugation or encapsulation of hydrophobic drugs (liposomes, polymers, ...), therefore they improve the internalization of the drug itself by several mechanism of internalization; secondly, the conjugation of the drug can inactivate the drug into a prodrug, and thus decrease the systemic toxicity. In that case, the drug can be released by a specific trigger once in the microenvironment of the tumor ( $\mathrm{pH}$, redox, heat, IR...) or in the cell. These release strategies are detailed in a recent review by Zhou et al. ${ }^{[35]}$. Finally, in the case of combination therapies, it allows the delivery at the same site of all the drugs, and also at a determined synergistic ratio ${ }^{[36]}$.

Furthermore, they allow the combination of several types of therapy ${ }^{[8]}$. Indeed, like nanoplatforms are multimodal, they can combine several properties. For example, the delivery of gene therapy is challenging because naked RNA and DNA are fast degraded in plasma. However, nanoparticles can protect them until delivery, and combine them with other therapies. It also can be used for photodynamic therapy, either by properties of the nanoparticle itself (nanoporphyrin) or by the surface functionalization with a photosensitizer. On the same idea, iron oxide nanoparticles (ION) can be used for photothermal therapy, and other type of nanoparticles can be used for immunotherapy (drug-conjugate...).

In that line of idea, Chen et al. ${ }^{[37]}$ developed an ultrasound triggered multimodal nanoparticle. They designed it for metastatic colorectal cancer: they formed microbubbles (used as contrast agent for ultrasound imaging) by combining porphyrin grafted lipid (enables photodynamic therapy and fluorescent imaging) and amphiphilic drug conjugate (hydrophobic camptothecin conjugated with hydrophilic fluouridine by a hydrolysable ester function). This technique allowed really stable nanoparticles (no early release) with a great drug loading content. Once the microbubbles, followed by ultrasound imaging, are at the tumor site, they are converted into nanoparticles by ultrasound exposure. Thus, they are internalized into the cells, which the acidic environment enables the hydrolysis of the ester function and thus, the dissociation of the drug-drug conjugate. Furthermore, the use of the ultrasound combined to the PDT reduces the expression of ABCG2, a drug pomp efflux responsible for MDR.

The conversion of nanoparticles by an external stimulus is also a strategy used to overcome barriers of resistant cancer.

\section{Nanoparticles to overcome barriers of resistant cancer}

Nanoparticles can also improve drug-delivery to resistant tumors by overcoming pathophysiological barriers. This is well explained in a recent review by Liu et al. ${ }^{[9]}$. Nanoparticles can overcome extracellular barriers by adapting their size, their surface, or the drug leakage/prodrug according to different triggers in the tumor microenvironment: more acidic $\mathrm{pH}$ (6.5-7.2), an increase of redox potentials and MMPs overactivated. Some nanoplatforms can also target the tumor micro-environment: either by degradation of the extracellular matrix, either by a phototherapy-induce alteration of the microenvironment. Finally, they can overcome intracellular barriers, by getting free of lysosomes by different pathways (light excitation, ...).

\section{Bio-mimetic nanoparticles to overcome drug resistance in cancer}

Although nanoparticles are promising platforms for therapy, most of them are cleared prematurely from the system, by opsonization, and uptaken by the macrophages ${ }^{[38]}$. Thus, it is important to design stealthy nanoparticles. To palliate to this problem, some researchers focused on biology to develop bio-inspired nanoparticles which then are bio-compatible and stable in plasma and are naturally targeting some type of cells. They thought about camouflage nanoparticles with cell membranes. Though, Mu et al. ${ }^{[39]}$ used stem cell membranes to coat magnetic nanoparticles of iron oxide. Therefore, they obtained an image guided, photothermal, siRNA delivery platform. They validated the presence of membrane proteins on their coated 
nanoparticles by SDS-PAGE, and the capability of the platform to induce a thermal increase after activation by NIR and to deliver siRNA. The increase in cellular uptake was shown by fluorescence microscopy and flow cytometry in vitro. In vivo, they showed the ability of the system to image the tumor by MRI $24 \mathrm{~h}$ after the injection. The biodistribution have been improved compare to the iron oxide alone: although the accumulation into heart; lung and kidney was the same, the coating decreased liver and spleen accumulation and increased the tumor uptake significantly. With a similar strategy, Cheng et al. ${ }^{[40]}$ used a circulating tumor cells' membrane to coat metal-organic framework nanoparticle. This system allows encapsulation of therapeutic proteins, here gelonin. They optimized the synthesis to obtain 100-nm nanoparticles and showed an in vitro decrease of the uptake of nanoparticles by macrophages, and an increase uptake by tumor cells. The selectivity towards tumor cells was proved. Indeed, healthy murine cells didn't show any uptake in vitro. The in vivo biodistribution showed an increased tumor uptake and a decreased uptake by liver, and a better treatment efficiency than MOF or proteins treatment. Finally, He et al ${ }^{[4]}$ combined membranes from two cell types (tumor cells and leukocyte) in order to combine the ability to thwart the detection by immune system of the leukocytes and the homotypic targeting of the tumor cells. They confirmed the combination of the two membranes by fluorescence and the presence of the cell biomarkers. They encapsulate Paclitaxel into these leutusomes. They show that the leukocyte membranes decreased the leukocyte uptake of the nanoparticles and that the tumor cell membrane increased the tumor cells uptake in vitro. They show a decreased in tumor size in vivo and no systemic toxicity.

\section{NANOPARTICLES INTO CLINICS: WHAT ARE THE LIMITS?}

Although nanoparticles have been wild investigated this last few years for therapeutic applications, few of them have been FDA approved. Indeed, the lack of established standard for the evaluation of nanoparticles limits their developments into clinics. During a workshop, researchers tried to define the challenges and some solutions and report it into a review ${ }^{[42]}$.

The challenges of nanomedicine start as soon as the design of the treatment: indeed, nanoparticles solution is a distribution of size, shape, molecular weight, ... Therefore, it complicates their physico-chemical characterization, and the establishment of their properties. It raises the question of what the criteria are to consider two different synthesis batches of nanoparticles as the same. Mülhopt et al ${ }^{[43]}$ realized studies on a large scale of nanomaterial of the variability of a large numbers of parameters. Although size is generally well controlled, and measurements repeatable, other parameters, like impurities are more variable and impacts on Reactive Oxygen Species (ROS) generation for example.

Furthermore, despite the EPR effect, a small amount of the injected dose really reached the tumor site. Wilhelm et al. ${ }^{[4]}$ showed on a large data set that regardless of the nanoparticle size, the delivery efficiency to the tumor site do not exceed $1 \%$. This is not a problem if the nanoparticles injected aren't toxic, but it is a challenge for drug delivery. Indeed, it has been shown that nanoparticles have a premature clearance, by several mechanisms. Blanco et al. ${ }^{[38]}$ have studied the biodistribution of nanoparticles according to " $4 \mathrm{~S}$ parameters": shape, size, stiffness and surface functionalization. Spherical nanoparticles under $5 \mathrm{~nm}$ are cleared by renal elimination. The other ones tend to accumulate into liver or lung. Most nanoparticles are opsonized and sequestered by the mononuclear phagocyte system. The challenge is thus to extend the blood circulation of nanoparticles, and to define the toxicity of nanoparticles for the organ into which they accumulate. Indeed, the toxicity of nanomaterials is still not well known; particularly for the liver, though, the toxicity toward hepatic cells should be well studied ${ }^{[45]}$.

When the nanosystem has been proved to be relevant in pre-clinical studies, there is still lots of barriers for the translational development: the scale-up is often difficult, regulatory and money, safety and efficacy, clinical adoption ${ }^{[46]}$. 


\section{INHIBITION OF HSP9O ISOFORMS, A PROMISING APPROACH TO POTENTIATE CONVENTIONAL THERAPY \\ HSP90 family}

HSPs are a family of proteins, classified by their weight, discovered in the laboratory of Ferrucio Ritossa ${ }^{[47]}$. The HSP90 family are highly conserved and localized in different organelles (inducible HSP90- $\alpha$ and constitutive HSP90- $\beta$ in the cytosol, GRP94 in the endoplasmic reticulum, and TRAP1 in the mitochondria).

These proteins are part of a chaperone machinery ${ }^{[48]}$, achieving stabilization and maturation of client proteins (over 200 for HSP90 $\alpha / \beta$, actualized list of the cytosolic HSP9o clients available at https://www.picard.ch/ downloads/HSP9ointeractors.pdf). This is possible by a cycle involving co-chaperones and other heat-shocks proteins. Thus, a complex formed by HSP70 and HSP 40 allows to partially fold some client proteins, and to transfer it to HSP90 thanks to a co-chaperone: HOP. Others co-chaperones are involved during the cycles: they bind to a specific conformation of HSP90, in a sequential manner. They stabilize HSP90 in a given conformation, regulates ATPase activity of HSP90, though regulates the cycle of HSP90... Depending on the type of client protein, the co-chaperone implicated in the machinery can be different. The HSP9o proteins have mainly 3 domains: the $\mathrm{N}$-terminal domain which is responsible for ATP-binding, the middle domain which allows the binding of co-chaperone and client proteins and the C-terminal domain which enables the dimerization of HSP90 proteins.

The expression of HSP90 and other heat-shocks proteins are regulated by a transcriptional factor: HSF-1. But HSF-1 is also a client protein of HSP70 and HSP90. The complex formed by these 3 proteins keeps HSF-1 in an inactive state. In case of stress, HSF-1 is released and enables the Heat Shock Response (HSR) to induce HSP genes. Other regulations involving post-translational modifications are explained in a review by Prodromou ${ }^{[49]}$.

HSP9o has various client proteins, involved in several important pathways like apoptosis, cell cycle control, cell viability and signaling events. These client proteins are summarized in Figure 2. Furthermore, their overexpression has been linked to several types of cancer (breast, melanoma, leukemia, colon carcinoma, non-small-cell lung cancer, prostate cancer... $)^{[48]}$. Thus, this family is an interesting target to overcome resistance. Indeed, like they are involved in all the hallmarks of cancer, and several pathways of intracellular signaling. Among them, there are survival and proliferation pathways, detailed above. The client proteins of HSP90 involved in drug resistance are listed below, in Table 1. Furthermore, the HSP90 chaperone machinery is able to avoid misfolding and degradation of mutated and overexpressed proteins, hence promoting cancer cell survival ${ }^{[50]}$.

In the last few years, HSP90 inhibitors were developed, with no paralog specificity but a binding capacity to the N-terminal domain of the protein. Several inhibitors went to clinical trials (over 50 clinical trials with 15 different $\mathrm{N}$-terminal inhibitors ${ }^{[53,54]}$ ), but none were FDA approved. Indeed, the $\mathrm{N}$-terminal binding induces a HSR by releasing HSF1 of HSP90, and thus a resistance to HSP90 inhibition ${ }^{[55]}$. Hence, several strategies emerged; the targeting of HSP9o by the C-terminal domain, or the middle domain; and the specific inhibition of a paralog. Indeed, Wang and McAlpine showed that the domain targeted have an influence on the phenotype and the heat-shock response ${ }^{[53]}$. They compared the effect of two chemical inhibitors on HCT-116 cells: $17-\mathrm{AAG}\left(\mathrm{GI}_{50}=50 \mathrm{nmol} / \mathrm{L}\right)$, which binds to the N-terminal domain; and SM122 $\left(\mathrm{GI}_{50}=8 \mu \mathrm{mol} / \mathrm{L}\right)$ which binds to the C-terminal domain. They compared the activity of these two inhibitors and a heat shock event at 3 levels: the accumulation of unfolded proteins, the expression of $3 \mathrm{mRNA}$, and the transcription of 3 proteins. Interestingly, the level of unfolded proteins increased significantly whereas the cells were treated with 17-AAG or SM122, and the result of these treatments were similar to a heat shock event. Then, they focused on the mRNA expression of inducible HSP70 (gene HSPA1A), constitutively expressed HSC70 (HSPPA8) and HSP27 (HSB1). Both treatments with 17-AAG and heat-shock event gave similar results, with an increased expression of these 3 genes whereas the treatment with SM122 showed a down-regulation of these three genes. Finally, 


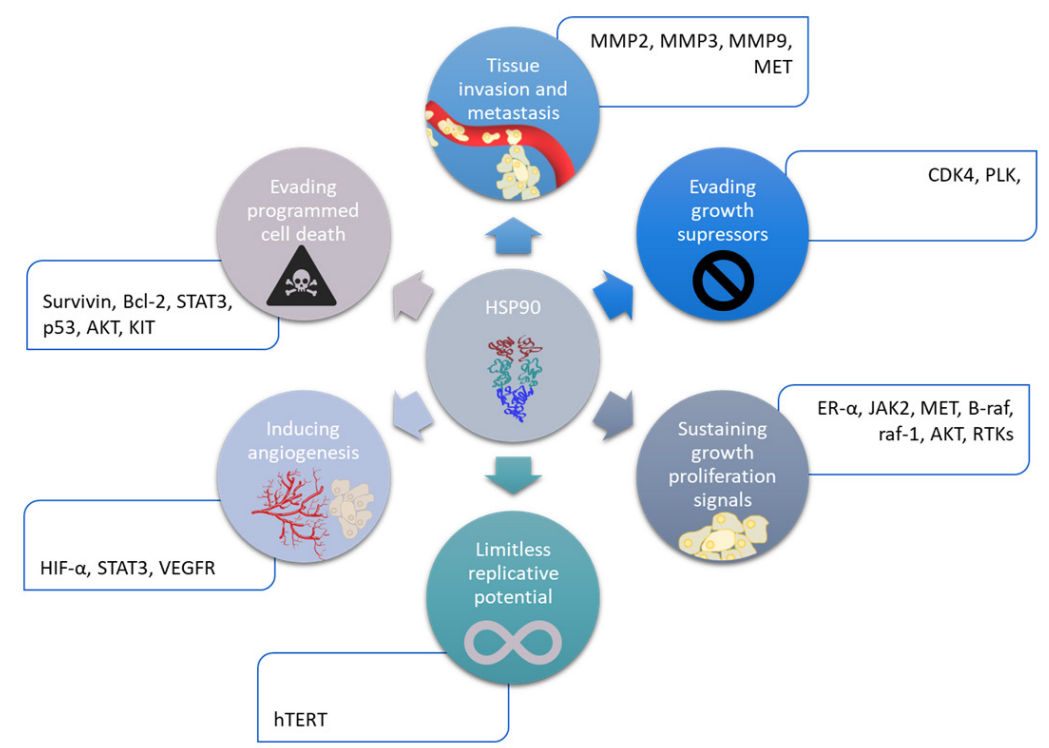

Figure 2. Implication of HSP9O family in the hallmarks of cancer. HIF- $\alpha$ : hypoxia inducible factor $\alpha$

Table 1. Summary of different HSP90 client proteins involved in drug resistance mechanisms ${ }^{[48,50,51,52]}$

\begin{tabular}{|c|c|c|c|}
\hline Class of proteins or pathway & $\begin{array}{l}\text { Client protein of } \\
\text { HSP90 family }\end{array}$ & Involved in mechanism resistance & Implicated cancers \\
\hline \multirow[t]{4}{*}{ Surface receptors } & HER2 & Promotes cell proliferation and opposes apoptosis & Breast, ovarian \\
\hline & EGFR & Promotes cell migration, adhesion and proliferation & NCSLC and glioblastoma \\
\hline & VEGFR & Promotes angiogenesis and cell migration & Various cancers \\
\hline & KIT & Activation of pro-survival pathway & GIST \\
\hline \multirow{8}{*}{$\begin{array}{l}\text { Cell } \\
\text { signaling }\end{array}$} & AKT & Intracellular signaling involved in the regulation of & Lung \\
\hline & FLT-3 & apoptosis, cellular cycle and angiogenesis & AML \\
\hline & MET & & Melanoma, gastric, lung \\
\hline & JAK2 & & Lymphoma \\
\hline & Raf1 & Signaling proliferation & Melanoma \\
\hline & B-raf & & Melanoma \\
\hline & MET & & Melanoma \\
\hline & JAK2 & & Lymphoma \\
\hline \multirow[t]{4}{*}{ Transcription factors } & $H I F-\alpha$ & Promoting angiogenesis & Renal \\
\hline & $E R-\alpha$ & Regulating genes involved in cellular proliferation & Breast \\
\hline & p53 & $\begin{array}{l}\text { Transcription of genes involved in cell cycle arrest or } \\
\text { apoptosis }\end{array}$ & $50 \%$ of cancers \\
\hline & STAT3 & Apoptosis, immunity and angiogenesis & \\
\hline \multirow[t]{3}{*}{ Damage response } & BRCA1/BRCA2 & $\begin{array}{l}\text { Transcription regulation, DNA repair and } \\
\text { ubiquitination }\end{array}$ & Breast, ovarian, prostate \\
\hline & RAD51 & DNA repair & \\
\hline & Chk1 & DNA damage response and cycle checkpoint response & AML \\
\hline \multirow[t]{2}{*}{ Apoptosis } & $\mathrm{Bcl}-2$ & Regulates mitochondrial apoptotic pathway & Follicular lymphoma/SCLC \\
\hline & Survivin & Inhibitor of apoptosis & GBM \\
\hline \multirow[t]{2}{*}{ Extracellular matrix } & $\begin{array}{l}\text { MMP2, MMP3, } \\
\text { MMP9 }\end{array}$ & $\begin{array}{l}\text { Facilitates invasion through cell adhesion, matrix } \\
\text { digestion and cell migration }\end{array}$ & Various cancers \\
\hline & FAK & Actin-based cell motility & Breast, colon \\
\hline \multirow[t]{2}{*}{ Kinases } & PLK & $\begin{array}{l}\text { Ser/Thr protein kinase - } \\
\text { Cell regulation (G2/M trigger) }\end{array}$ & Lung, colon, AML \\
\hline & CDK4 & Cytokine kinase - cell cycle regulation & CML \\
\hline \multirow[t]{2}{*}{ Chimeric fusion protein } & BCR-ABL & $\begin{array}{l}\text { Activates numerous signal transduction pathways in } \\
\text { leukemogenesis }\end{array}$ & CML \\
\hline & NPM-ALK & Induces cell transformation and proliferation & Anaplastic lymphoma \\
\hline
\end{tabular}

NCSLC: non small cell lung cancer; GIST: gastrointestinal stromal tumor; AML: acute myeloid leukemia; GBM: glioblastoma; CML: chronic myeloid leukemia 
the treatment with 17-AAG and the heat shock event both induced an increased level of HSP70, HSP27 and HSF1 proteins, although the treatment with SM122 showed a decrease protein level for the same ones. To conclude, $\mathrm{N}$-terminal and $\mathrm{C}$-terminal modulators have different phenotype.

Afterwards, some groups focused on C-terminal binding inhibitors, and showed its activity without HSR. Alami/Messaoudi ${ }^{[5-59]}$ and Blagg ${ }^{[0,61]}$ groups developed independently some C-terminal inhibitors based on a natural inhibitor: novobiocin. Terracciano et al. ${ }^{[62]}$ developed two other inhibitors, different from novobiocin, and shows that they induces different kinds of response than novobiocin based inhibitors but no HSR as well. At last, some groups studied the inhibition by the middle domain and found no HSR and an induction of apoptosis ${ }^{[63]}$. Bhatia et al ${ }^{[64]}$ showed the interest of C-terminal inhibitor to tackle imatinibresistant chronic myeloid leukemia (CML). Hyun et al. ${ }^{[65]}$ designed a new C-terminal inhibitor by mixing structures of two inhibitors of HSP90 in order to circumvent drawbacks of both inhibitors: novobiocin, which has a high $\mathrm{IC}_{50}$ of $700 \mu \mathrm{mol} / \mathrm{L}$, and deguelin, which has important sides toxic effect. This new inhibitor showed inhibitory effects on viability and colony formation on NSCLC cells and chemoresistant cells, whereas it showed minimal effect on viability of normal cells.

This kind of inhibitors are exhaustively described in a review ${ }^{[66]}$, and they have shown to sensitize cancer cells to lots of chemotherapies (in various cancer: breast, prostate, ovarian, melanoma, glioblastoma, leukemia, myeloma,.... $)^{[67]}$.

Another strategy to improve HSP90 inhibitors efficacy in translational medicine is to selectively target isoforms, either by improving the specificity towards the targets (crystal studies, ...), either by targeting an organelle (intracellular compartment). These more selective inhibitors would have more specific actions, and thus would be less toxic.

\section{INHIBITION OF ORGANELLE SPECIFIC ISOFORMS HSP90 alpha/beta}

To decrease the HSP90-inhibition related toxicological effects, the selective inhibition of HSP90 $\alpha / \beta$ allows to reduce the number of client proteins involved, and not to touch to the functions of the mitochondria and the endothelial reticulum. So, Ernst et al. ${ }^{[68]}$ developed a specific inhibitor by studying the conformations of the different isoforms. The inhibitor developed shows a binding affinity of $5 \mathrm{nmol} / \mathrm{L}$ with HSP90 $\alpha / \beta$, whereas those of GRP94 and TRAP1 are above $10 \mu \mathrm{mol} / \mathrm{L}$. This strategy is efficient for some diseases (like Huntington's one), but its efficacy has not been proved yet in oncology and resistant cancers. Most of the groups have focused on the specific targeting of the other organelles (ER and mitochondria), which have less client proteins and so their inhibitors could be less toxic for healthy tissues. Furthermore, although the expression of HSP90- $\alpha$ is not critical for healthy cell viability, the one of HSP90- $\beta$ is ${ }^{[69]}$. Whereas, the expression of both GRP94 and TRAP1 aren't vital for healthy cells ${ }^{[70,71]}$.

\section{GRP94}

GRP94 is mainly located in the ER and shares 50\% homology with HSP90 cytosolic ${ }^{[47]}$. It has the same ATPase activity as cytosolic HSP90, however, it is the major calcium binding protein in the ER and has specific limited client proteins. GRP94 is involved in calcium homeostasis and ER quality control (protein folding, interaction with the protein folding machinery, calcium storage...).

GRP94 is involved in several pathways responsible for some drug resistances ${ }^{[72]}$. Indeed, it maintains ER $\mathrm{Ca}^{2+}$ homeostasis and thus protects cancer cells from apoptosis. It's also involved in PI3K-AKT pathway by binding some insulin-like growth factor (IGF1, IGF2) to their receptors. Furthermore, some integrins are also client proteins of GRP94, and are linked to invasion and metastasis. All these pathways can explain why GRP94 is linked to drug resistance in lots of tumors. 
Blagg group has worked on specific GRP94 selective inhibitions for a few years. They began to crystallize GRP94 and HSP90 to identify differences ${ }^{[73]}$. From that they determine 3 interesting scaffolds for this targeting (radamide, purine, NECA). Thus, they developed first GRP94 inhibitors from the radamide scaffold, with a binding affinity around $820 \mathrm{nmol} / \mathrm{L}$ for GRP94 and a good selectivity toward HSP90 $\alpha^{[74]}$. In the same time, another group worked on GRP94 inhibitors from purine-scaffold, and prove its selectivity with a binding affinity of $220 \mathrm{nmol} / \mathrm{L}$ for GRP $94,7 \mu \mathrm{mol} / \mathrm{L}$ for TRAP1 and above $25 \mu \mathrm{mol} / \mathrm{L}$ for HSP $90 \alpha / \beta^{[75]}$. Once the first inhibitors developed, they focus on NECA scaffold and the interaction with other structures to increase the binding efficiency, and create a new inhibitor with a 200 -fold selectivity (binding affinity of $440 \mathrm{nmol} / \mathrm{L}$ for GRP94 and above $100 \mu \mathrm{mol} / \mathrm{L}$ for HSP90 $\alpha)^{[76]}$. Afterwards, with the interaction studies of these inhibitors, they discovered new hydrophobic subpocket of GRP94, which allows a new type of GRP94 inhibitors scaffold: the resorcinol one. The first one showing a binding activity of $8 \mathrm{nmol} / \mathrm{L}$ with GRP94, and of $77 \mathrm{nmol} / \mathrm{L}$ with HSP $90 \alpha^{[77]}$. The second one showing a binding affinity of $4 \mu \mathrm{mol} / \mathrm{L}$ with GRP 94 , and no affinity for HSP90 $\alpha$ for the range of concentration tested. They showed in vitro with another resorcinol inhibitor (binding affinity of $0.54 \mu \mathrm{mol} / \mathrm{L}$ with GRP94 and a 73-fold selectivity towards other HSP90s) that the selective inhibition of GRP94 could decrease migratory abilities of cancer cells and thus be really useful in aggressive cancers ${ }^{[78]}$. Finally, they showed in vivo, with an open-angle glaucoma model that the selective inhibition of GRP94 shows less toxicities and undesirable effects ${ }^{[7]}$.

\section{TRAP1}

TRAP1 shares high homology with cytosolic HSP90, reflecting 34\% identity and 60\% similarity. However, it binds ATP with 10 -fold affinity than HSP90 ${ }^{[47]}$. Structurally, TRAP1 doesn't have a C-terminal MEEVD motif and a charger linker domain connecting Middle Domain to C-terminal Domain, both found in HSP90a/ $\beta$. Furthermore, TRAP1 has a major role in the mitochondria: it maintains its integrity and protect against mitochondrial apoptosis ${ }^{[80-83]}$. It also protects against cell death by overproduction of ROS and inhibits oxidative phosphorylation by interacting with complexes of the respiratory chain (Succinate DeHydrogenase and cytochrome oxidase). These two last functions are involved in drug resistance mechanisms. TRAP 1 has been shown to be responsible for resistance to apoptosis and involved in MDR in several cancers (colorectal cancer $^{[80,84]}$, thyroid carcinoma ${ }^{[81]}$, breast cancer, NSCLC ${ }^{[82]}$, ovarian cancer, prostatic cancer, ...). So, the selective inhibition of TRAP1 can be interesting for resistant and aggressive cancers. Like GRP94, some studies on the crystal structures of TRAP1 interactions (mainly focused on the $\mathrm{N}$-terminal domain of the protein), allowed researchers to develop a specific inhibitor to TRAP $1^{[85]}$. They changed the purine ring of an HSP9o inhibitor into a pyrazolopyrimidine in order to decrease the binding of this inhibitor with HSP90 cytosolic and so increased its concentration into the mitochondria: thus, its binding affinity with TRAP1 is of $79 \mathrm{nmol} / \mathrm{L}$, whereas it is of $698 \mathrm{nmol} / \mathrm{L}$ for other analogs. Other groups developed specific TRAP1 inhibitors by using a mitochondrial delivery vehicle. Thus, in 2005 the Altieri group demonstrated that Shepherdin, a 17-AAG derivative carrying the antennapedia peptide, efficiently accumulates inside the mitochondria and inhibits the chaperone activity of TRAP-1 and HSP90 through a competition with ATP thus resulting in cell death involving the regulation of the mitochondrial transition pore opening ${ }^{[86]}$.

More recently, the same group developed gamitrinibs ${ }^{[87]}$. They combine an HSP90 inhibitor (17-AAG) with various linkers' length and a mitochondrial targeting moieties triphenylphosphium (TPP) as well as a guanidinium salts. The length of the linker (alkyle chains most of the time) influences on the mitochondrial matrix accumulation of the drug ${ }^{[88]}$, a long chain increases the octanol/water partition and thus the mitochondrial accumulation. The targeted 17-AAG derivated inhibitor has an $\mathrm{IC}_{50}$ between 4 and $20 \mu \mathrm{mol} / \mathrm{L}$ depending of cell-lines since the 17-AAG as a non-targeted drug has an IC-50 between 25 and over 200 $\mu \mathrm{mol} / \mathrm{L}$ for the same cell lines confirming the rationale to target mitochondria to enhance activity of HSP 90 inhibitors. Another group combined both approaches, hence combining a specific inhibitor of TRAP1 to a mitochondrial delivery vehicle ${ }^{[89]}$. They started with a 3,4 isoxazole diamide structure, to which they added spacers of various length and a cationic head (triphenylphosphonium, pyridinium salts, guanidinium, 
polyamine, ...). For now, they have similar binding affinities (in the nmol/L range) toward HSP90 and TRAP1, and thus need to be improved thanks to the crystal structure of TRAP1 (full length). However, they show an accumulation into the mitochondria, and good ATPase inhibition $\left(\mathrm{IC}_{50}\right.$ around $\left.500 \mathrm{nmol} / \mathrm{L}\right)$, an important cell proliferation inhibition $\left(\mathrm{IC}_{50}=1.32 \mu \mathrm{mol} / \mathrm{L}\right.$ ) and an induction of apoptosis starting as soon as $1 \mu \mathrm{mol} / \mathrm{L}$.

The conjugate Gamitrinib - triphenylphosphonium head has been studied in vitro and in vivo. It has been shown that it induces apoptosis, cell cycle arrest in G2-M phase, and an increase in ROS levels in liver cancer ${ }^{[0]}$. It has also been shown that it induces death in hepatocellular carcinoma cells through a combination of death pathways: necroptosis, apoptosis and autophagy ${ }^{[91]}$. Furthermore, G-TPP has shown good synergistic properties with Bcl-2 inhibitors ${ }^{[2]}$. As well, preclinical studies have been done in prostate cancer, and G-TPP has shown a good inhibition of cell growth $\left(\mathrm{GI}_{50}\right.$ between $1.10^{-7}$ and $\left.5.10^{-5} \mathrm{~mol} / \mathrm{L}\right)$ and a loss of metabolic activity with prostate cancer cells, multi-drug resistance prostate cancer cells and bone metastatic prostate cancer cells. This has also been tested in vivo ${ }^{[93]}$. No significant systemic or organ toxicity was observed.

\section{WHY TARGETING TRAP1 PROTEIN TO FIGHT CANCER?}

The intrinsic signal pathway for cell apoptosis and energetic metabolism (respiration and Krebs cycle) are mediated by mitochondria. Furthermore, TRAP1 takes part of a pro-survival cell pathway, which may lead to therapeutic resistance. Thus, it's an interesting organelle for targeted therapeutics ${ }^{[94]}$. It has been shown that TRAP1 is involved in resistance to DNA damaged induced by cis-platin and $\mathrm{H}_{2} \mathrm{O}_{2}^{[80]}$. Up to now, TRAP1 has been mainly considered as an oncogenic protein in many cancers (prostate, colorectal and breast cancers) but recently some evidences are in favor of the tumor suppressor role of TRAP-1 in some cancers as in ovarian cancer. That's why inhibition of TRAP-1 has to be chosen taking into account the potential role in tumor growth or survival ${ }^{[95]}$.

TRAP1 inhibits the succinate dehydrogenase, which stabilizes the factor Hypoxia Inducible Factor $1 \alpha$ (HIF $1 \alpha$ ) and though allow the neoplastic ${ }^{[83,96]}$. It also inhibits CYPD, so the permeability transition pore (PTP) can't open anymore, and the death signal isn't able to go into the cytosol anymore. Moreover, it inhibits the production of ROS species by binding with two complexes of the mitochondrial respiration (II and IV).

The Warburg effect, considered as a marker of cancerous cells for a long time, is not a universal feature of cancer anymore. Some tumors preferentially rely on oxidative phosphorylation mechanism rather than the aerobic glycolysis, preferred usually by cancer cells. Interestingly, some researches show that whereas TRAP1 favors oncogenic phenotypes in glycolytic tumors, it was down-regulated in tumors relying on oxidative mechanisms ${ }^{[97]}$. This correlates with the fact that TRAP1 has been shown by Yoshida et al. ${ }^{[70]}$ to regulate the cellular respiration: a reduced or absent expression of TRAP1 would favorize oxidative phosphorylation whereas a high expression of TRAP1 would favorize aerobic glycolysis ${ }^{[70]}$.

Some studies showed the presence of TRAP1 in the ER, and enlighten its involvement in ER stress protection and therefore the interest of targeting endoplasmic TRAP1 to overcome drug resistance ${ }^{[98]}$.

Although all the inhibitors described above and targeting HSP90 isoforms are promising, most of them are water insoluble. Thus, administration of those drugs is limited. A solution to this problem is to use nanoparticles to administer these drugs, Furthermore, this could allow to deliver a combination therapy with more precision, and to actively and selectively target tumors in order to avoid systemic and organ toxicity. 
Table 2. Impact of HSP9O inhibitors on client protein-based resistance pathways

\begin{tabular}{|c|c|c|c|c|c|}
\hline HSP90 inhibitor & $\begin{array}{c}\text { Type of cancer/clinical } \\
\text { phase }\end{array}$ & Combinations with & $\begin{array}{l}\text { Overcoming resistance } \\
\text { to }\end{array}$ & $\begin{array}{l}\text { Client proteins/pathway } \\
\text { involved }\end{array}$ & Ref. \\
\hline $\begin{array}{l}\text { 17-AAG } \\
\text { (Benzoquinone } \\
\text { derived) }\end{array}$ & $\begin{array}{l}\text { Human melanoma/ } \\
\text { Preclinical }\end{array}$ & PI3K/mTORinhibitors & $\begin{array}{l}\text { BRAF inhibitors } \\
\text { mTOR inhibitors }\end{array}$ & $\begin{array}{l}\mathrm{PI} 3 \mathrm{~K} / \mathrm{AKT} / \mathrm{mTOR} \text { and } \\
\mathrm{RAS} / \mathrm{RAF} / \mathrm{MAPK}\end{array}$ & [99] \\
\hline $\begin{array}{l}\text { 3-COA } \\
\text { (Oleaonolic acid) }\end{array}$ & $\begin{array}{l}\text { Lung cancer } \\
\text { (Preclinical) }\end{array}$ & $\begin{array}{l}\text { Cisplatin or } \\
\text { Doxorubicin }\end{array}$ & $\begin{array}{l}\text { Cks1b-induced } \\
\text { chemoresistance } \\
\text { (Cisplatin and } \\
\text { doxorubicine) }\end{array}$ & AKT/MEK & [100] \\
\hline \multirow[t]{5}{*}{$\begin{array}{l}\text { AUY922 } \\
\text { (resorcinol derived) }\end{array}$} & $\begin{array}{l}\text { P53-mutant Head and } \\
\text { neck cancer } \\
\text { (preclinical) }\end{array}$ & $\begin{array}{l}\text { Concurrent Cisplatin } \\
\text { radiotherapy }\end{array}$ & DNA damages & p53, RAD51, ChK1, BRCA1 & [101] \\
\hline & $\begin{array}{l}\text { Mantle cell lymphoma } \\
\text { (Preclinical/phase1/ } \\
\text { phase2) }\end{array}$ & Preclinical, alone & $\begin{array}{l}\text { Ibrutinib (bruton } \\
\text { tyrosine kinase } \\
\text { inhibitor) }\end{array}$ & $\begin{array}{l}\text { Bruton tyrosine kinase, } \\
\text { JAK2 }\end{array}$ & [102] \\
\hline & $\begin{array}{l}\text { KRAS-mutant NSCLC } \\
\text { (preclinical) }\end{array}$ & $\begin{array}{l}\text { GSK458 (PI3K } \\
\text { inhibitor) }\end{array}$ & PI3K inhibitor & AKT and RAF & [103] \\
\hline & $\begin{array}{l}\text { KRAS-mutant NSCLC } \\
\text { (Preclinical) }\end{array}$ & $\begin{array}{l}\text { Trametinib (MEK } \\
\text { inhibitor) }\end{array}$ & MEK inhibitors & $A K T$ and RAF & [104] \\
\hline & $\begin{array}{l}\text { Breast cancer } \\
\text { (Preclinical) }\end{array}$ & Fulvestrant & Hormone treatments & ErbB receptors & [105] \\
\hline $\begin{array}{l}\text { AUY922/AT13387 } \\
\text { (HSP90/ALK } \\
\text { inhibitor) }\end{array}$ & $\begin{array}{l}\text { Lung adenocarcinoma } \\
\text { (In vitro studies) }\end{array}$ & $\begin{array}{l}\text { Dual targeting } \\
\text { inhibitor }\end{array}$ & ALK inhibitors & HER2, ATK, ALK & [106] \\
\hline $\begin{array}{l}\text { Gamitrinib (TRAP1 } \\
\text { inhibitor) }\end{array}$ & & & Apoptosis resistance & $\mathrm{Bcl}-2$ & {$[91]$} \\
\hline \multirow[t]{3}{*}{ Ganetespib } & $\begin{array}{l}\text { Breast cancer } \\
\text { (preclinical studies) }\end{array}$ & $\begin{array}{l}\text { ABT-888 (PARP } \\
\text { inhibitor) and ionizing } \\
\text { radiation }\end{array}$ & PARP inhibitors & $\begin{array}{l}\text { Core proteins in the DNA } \\
\text { repair machinery (BRCA1, } \\
\text { BRCA2, RAD51) }\end{array}$ & [107] \\
\hline & $\begin{array}{l}\text { Breast cancer } \\
\text { (preclinical studies) }\end{array}$ & $\begin{array}{l}\text { Zinc phtalocyanine } \\
\text { conjugate } \\
\text { (photosensitizer) }\end{array}$ & ROS & $\begin{array}{l}\text { HSP90 extracellular } \\
\text { (targeting) } \\
\text { HIF } 1 \alpha \text {, surviving, VEGF }\end{array}$ & [108] \\
\hline & $\begin{array}{l}\text { Metastatic breast cancer } \\
\text { (phase I clinical trials) }\end{array}$ & $\begin{array}{l}\text { Paclitaxel and } \\
\text { trastuzumab } \\
\text { (anti-HER2 antibody) }\end{array}$ & Anti-HER2 resistance & RTKs & [109] \\
\hline KW-2478 & $\begin{array}{l}\text { Multiple Myeloma } \\
\text { (Phase I/II study) }\end{array}$ & Bortezomib & Relapsed/refractory & & [110] \\
\hline
\end{tabular}

WILL A COMBINATION OF BOTH HSP9O INHIBITION AND THE USE OF DRUG DELIVERY NANOSYSTEMS GIVE ADVANTAGES TO TREAT AGGRESSIVE AND DRUG RESISTANT CANCER? Inhibitors of HSP90 in combination for drug resistance

HSP9o has been tested in combination therapies by several groups and has shown great synergism with different other drugs, to overcome resistances. These studies are summarized in Table 2. The combination of both is thus relevant to overcome resistances.

\section{HSP90 targeting-nanoparticles to sensitize cancerous cells}

Some HSP90 targeting-nanoparticles have already been developed, and detailed in a previous review by Sauvage et al. ${ }^{[111]}$. Since this review, the nanoparticles have been improved, and new ones had been designed. There is still few of them designed with an organelle specific inhibitor, but pan-inhibitors have been incorporated into nanoparticles to sensitize resistant cancers.

The pan-inhibitor 17-AAG has been encapsulated in micelles by Le et al. ${ }^{[112]}$. It was co-encapsulated with rapamycin, a mTOR inhibitor, and docetaxel, an anti-mitotic. They designed this nanoparticle to target multiple pathways in order to treat advanced prostate cancers which are resistant to all current therapies. They have shown that this system targets simultaneously several signaling axes, including mTOR and PIK3/AKT pathways. This led to increased cytotoxicity effects and to an in vitro and in vivo growth tumor inhibition by caspase-dependent pathway. 17-AAG has also been integrated to a nanogel with another combination 
therapy as reported by Shin et al. ${ }^{[113]}$ : Epothilone B, an inhibitor of microtubules, and rapamycin. This formulation has been developed to overcome chemoresistance against microtubules stabilizing agents in an ovarian tumor model. They found an optimistic ratio of these three drugs (0.4:3.0:1.5, EpoB/17AAG/Rap), which exhibits a strong synergy with an $\mathrm{IC}_{50}$ of $3 \mathrm{nmol} / \mathrm{L}$, and a decreased clonogenicity. This formulation is thermosensitive, which allows a triggered release of the drugs, and so less systemic and organ toxicity. In vivo, it has been safely injected by i.p., and a decreased of metastasis has been observed.

However, nanosystems not only enable easy combination therapy delivery, but also enable combination of several types of therapies. Thus, Peng et al. ${ }^{[14]}$ developed a thermoresponsive polymer to achieve both chemotherapy (17-AAG) and photothermal therapy (IR780, photosensitizer) at the tumor site. Release of drugs is triggered by heat, while IR780 is excited for the photothermal ablation therapy (polymer micelles reaches 50 ${ }^{\circ} \mathrm{C}$ ). This system has been designed for overcoming resistance to heat shock event. A synergistic cell death has been noticed in vitro in colon cancer cell lines, as well as a suppression of growth tumor in vivo.

Another system allows the combination of three types of therapy: photothermal therapy (PTT), photodynamic therapy (PDT) and chemotherapy. It is a nanoporphyrin platform loaded with 17-AAG ${ }^{[115]}$. HSP9o sensitizes cells to ROS species and heat shock event. This platform showed a strong synergistic inhibition of cell proliferation. The authors studied the molecular mechanism, and found an increase of HSP70, as well as a decrease of HIF $1 \alpha$, ERK, AKT and Src decrease, characteristic of an HSP90 inhibition by a N-terminal modulator. Even if there was no active targeting, a monitoring by NIR imaging was possible thanks to porphyrins physical properties. This allowed an excitation of the porphyrin when accumulated into the tumor site.

Although the previous systems encapsulated a $\mathrm{N}$-terminal inhibitor, we developed a liposomal system in which a C-terminal inhibitor $6-\mathrm{BrCaQ}^{[116,117]}$ has been encapsulated as well. It has been encapsulated in liposomes and administered in vivo to mice bearing a triple negative breast cancer model. In vitro studies showed an induction of apoptosis, an anti-proliferation effect, a decrease of cellular migration and a decrease of the levels of client proteins of HSP90. In vivo studies showed a decrease of tumoral growth. Another group formulated $\mathrm{pH}$-responsive polymeric nanoparticles with a new compound, a polar cyclic peptide (LB76) identified as a C-terminal inhibitor of HSP9o but unable to cross cell membranes. These particles allow endocytosis and favorize activity in a colorectal cancer cell line $\mathrm{e}^{[118]}$.

To induce drug sensitivity to late stages resistant cancer, Banerjee group developed a glucocorticoid liposomal delivery system ${ }^{[119,120]}$ which target HSP9o by a mRNA. This lipoplex coformulated an anti-HSP90 mRNA (amiR-HSP90) and a drug which down-regulates mTOR pathway (ESC8). This liposomal formulation presented dexamethasone to target glucocorticoid receptor, overexpressed in cancer cells. This system has been tested in pancreas cancer cell lines and melanoma cancer cell lines and show antitumor activity. More interestingly, it shows a reverse drug resistance by downregulating a drug transporter protein: ABCG2. Thus, it showed impressive synergistic effect with doxorubicin.

\section{WHAT'S NEXT?}

Whereas pan-HSP90 inhibitors have been encapsulated in various nanosystems, there are few nanoparticles for the delivery of organelle specific inhibitor. This strategy could be imagined either by encapsulating a specific inhibitor in a nanoplatform, either by adding an organelle targeting on the surface of the nanoparticle. For instance, some groups have worked on nanosystems presenting both CD44 targeting and mitochondrial targeting ${ }^{[25,121-124]}$. These dual targeting could allow to significantly reduce toxicity: the drug is delivered to the tumor site, which reduce systemic toxicity, and then the targeting of mitochondria could allow a specific inhibition of TRAP1. 


\section{CONCLUSION}

In this review, we highlighted the HSP90 chaperone machinery as an interesting target for drug resistant cancer, as well as the importance of nanocarriers to overcome physiological barriers to deliver therapeutics and to improve drug efficacy without increasing side effects. We underlined the usefulness of nanoparticles to administer combination therapies, to improve the efficiency of the treatment. Moreover, these systems can target a specific biomarker, which allow a specific delivery to cells responsible for the cancer invasiveness (stem cell-like cancer cells, metastatic cells...). We strongly believed that the future treatments should rely on the use of an organelle specific HSP90 inhibitor combine to nanotechnology to improved targeting, and eventually combination therapies.

\section{DECLARATIONS}

\section{Acknowledgments}

Authors want to thank Dr. François Fay for his help in the design of the Figure 1.

\section{Authors' contributions}

Mathieu C wrote the major parts of the manuscript under the supervision of Vergnaud-Gauduchon J, Fattal $\mathrm{E}$ and Messaoudi S. The organization of the manuscript was discussed with all authors and each supervisor corrected the part related to his main competences: Fattal E, nanomedicine, Messaoudi S, Chemistry and HSP9o inhibitors, Vergnaud-Gauduchon, biological mechanisms and HSP90.

\section{Availability of data and materials}

Not applicable.

\section{Financial support and sponsorship}

Authors would like to thank Ecole Normale Supérieure de Lyon for the «contrat doctoral spécifique pour normaliens», a French doctoral fellowship for Mathieu C. For research support and administrative support, we thank the Centre National de la Recherche Scientifique (CNRS), Paris-Sud University (Paris-Saclay University). Part of the works cited in this review have been granted by Ligue Contre le Cancer (comité des Hauts de seine, \#4FI10626MIUR) and Fondation ARC (\#SFI20111203965).

\section{Conflicts of interest}

All authors declared that there are no conflicts of interest.

\section{Ethical approval and consent to participate}

Not applicable.

\section{Consent for publication}

Not applicable.

\section{Copyright}

(c) The Author(s) 2019.

\section{REFERENCES}

1. Nussinov R, Tsai CJ, Jang H. A new view of pathway-driven drug resistance in tumor proliferation. Trends Pharmacol Sci 2017;38:42737.

2. Gentric G, Mieulet V, Mechta-Grigoriou F. Heterogeneity in cancer metabolism: new concepts in an old field. Antioxid Redox Signal 2016;26:462-85.

3. Gupta PB, Pastushenko I, Skibinski A, Blanpain C, Kuperwasser C. Phenotypic plasticity: driver of cancer initiation, progression, and therapy resistance. Cell Stem Cell 2019;24:65-78. 
4. Vargas-Roig LM, Gago FE, Tello O, Aznar JC, Ciocca DR. Heat shock protein expression and drug resistance in breast cancer patients treated with induction chemotherapy. Int J Cancer 1998;79:468-75.

5. Stope MB, Koensgen D, Burchardt M, Concin N, Zygmunt M, et al. Jump in the fire - heat shock proteins and their impact on ovarian cancer therapy. Crit Rev Oncol Hematol 2016;97:152-6.

6. Yallowitz A, Ghaleb A, Garcia L, Alexandrova EM, Marchenko N. Heat shock factor 1 confers resistance to lapatinib in ERBB2positive breast cancer cells article. Cell Death Dis 2018;9:621.

7. Ozben T. Mechanisms and strategies to overcome multiple drug resistance in cancer. FEBS Lett 2006;580:2903-9.

8. Jang B, Kwon H, Katila P, Lee SJ, Lee H. Dual delivery of biological therapeutics for multimodal and synergistic cancer therapies. Adv Drug Deliv Rev 2016;98:113-33.

9. Liu JP, Wang TT, Wang DG, Dong AJ, Li YP, et al. Smart nanoparticles improve therapy for drug-resistant tumors by overcoming pathophysiological barriers. Acta Pharmacol Sin 2017;38:1-8.

10. Zhang RX, Wong HL, Xue HY, Eoh JY, Wu XY. Nanomedicine of synergistic drug combinations for cancer therapy - Strategies and perspectives. J Control Release 2016;240:489-503.

11. Cardoso F, Bedard PL, Winer EP, Pagani O, Senkus-Konefka E, et al. International guidelines for management of metastatic breast cancer: combination vs sequential single-agent chemotherapy. J Natl Cancer Inst 2009;101:1174-81.

12. Zhang B, Hu Y, Pang Z. Modulating the tumor microenvironment to enhance tumor nanomedicine delivery. Front Pharmacol $2017 ; 8: 952$.

13. Tashima T. Effective cancer therapy based on selective drug delivery into cells across their membrane using receptor-mediated endocytosis. Bioorganic Med Chem Lett 2018;28:3015-24.

14. Cui J, Yue JB. Current status and advances in arginine-glycine-aspartic acid peptide-based molecular imaging to evaluate the effects of anti-angiogenic therapies. Precis Radiat Oncol 2019;3:29-34.

15. Carpenter RO, Evbuomwan MO, Pittaluga S, Rose JJ, Raffeld M, et al. B-cell maturation antigen is a promising target for adoptive T-cell therapy of multiple myeloma. Clin Cancer Res 2013;19:2048-60.

16. Acres B, Limacher JM. MUC1 as a target antigen for cancer immunotherapy. Expert Rev Vaccines 2005;4:493-502.

17. Mattheolabakis G, Milane L, Singh A, Amiji MM. Hyaluronic acid targeting of CD44 for cancer therapy: from receptor biology to nanomedicine. J Drug Target 2015;23:605-18.

18. Saneja A, Arora D, Kumar R, Dubey RD, Panda AK, et al. CD44 targeted PLGA nanomedicines for cancer chemotherapy. Eur J Pharm Sci 2018;121:47-58.

19. Necas J, Bartosikova L, Brauner P, Kolar J. Hyaluronic acid (hyaluronan): a review. Vet Med (Praha) 2008;53:397-411.

20. Sun Y, Li X, Zhang L, Liu X, Jiang B, et al. Cell permeable NBD peptide-modified liposomes by hyaluronic acid coating for the synergistic targeted therapy of metastatic inflammatory breast cancer. Mol Pharm 2019;16:1140-55.

21. Dufay Wojcicki A, Hillaireau H, Nascimento TL, Arpicco S, Taverna M, et al. Hyaluronic acid-bearing lipoplexes: physico-chemical characterization and in vitro targeting of the CD44 receptor. J Control Release 2012;162:545-52.

22. Nascimento TL, Hillaireau H, Vergnaud J, Fattal E. Lipid-based nanosystems for CD44 targeting in cancer treatment: recent significant advances, ongoing challenges and unmet needs. Nanomedicine 2016;11:1865-87.

23. Dosio F, Arpicco S, Stella B, Fattal E. Hyaluronic acid for anticancer drug and nucleic acid delivery. Adv Drug Deliv Rev 2016;97:20436.

24. Nascimento TL, Hillaireau H, Noiray M, Bourgaux C, Arpicco S, et al. Supramolecular organization and siRNA binding of hyaluronic acid-coated lipoplexes for targeted delivery to the CD44 receptor. Langmuir 2015;31:11186-94.

25. Lee SY, Cho HJ. Mitochondria targeting and destabilizing hyaluronic acid derivative-based nanoparticles for the delivery of lapatinib to triple-negative breast cancer. Biomacromolecules 2019;20:835-45.

26. Tevaarwerk AJ, Kolesar JM. Lapatinib: a small-molecule inhibitor of epidermal growth factor receptor and human epidermal growth factor receptor-2 tyrosine kinases used in the treatment of breast cancer. Clin Ther 2009;31:2332-48.

27. Zhang M, Ma Y, Wang Z, Han Z, Gao W, et al. A CD44-targeting programmable drug delivery system for enhancing and sensitizing chemotherapy to drug-resistant cancer. ACS Appl Mater Interfaces 2019;11:5851-61.

28. Lu L, Ding Y, Zhang Y, Ho RJY, Zhao Y, et al. Antibody-modified liposomes for tumor-targeting delivery of timosaponin AIII. Int J Nanomedicine 2018;13:1927-44.

29. Kennedy PJ, Sousa F, Ferreira D, Pereira C, Nestor M, et al. Fab-conjugated PLGA nanoparticles effectively target cancer cells expressing human CD44v6. Acta Biomater 2018;81:208-18.

30. Alshaer W, Hillaireau H, Fattal E. Aptamer-guided nanomedicines for anticancer drug delivery. Adv Drug Deliv Rev 2018;134:122-37.

31. Ismail SI, Alshaer W. Therapeutic aptamers in discovery, preclinical and clinical stages. Adv Drug Deliv Rev 2018;134:51-64.

32. Alshaer W, Hillaireau H, Vergnaud J, Ismail S, Fattal E. Functionalizing Liposomes with anti-CD44 aptamer for selective targeting of cancer cells. Bioconjug Chem 2015;26:1307-13.

33. Alshaer W, Hillaireau H, Vergnaud J, Mura S, Deloménie C, et al. Aptamer-guided siRNA-loaded nanomedicines for systemic gene silencing in CD-44 expressing murine triple-negative breast cancer model. J Control Release 2018;271:98-106.

34. Lou S, Zhao Z, Dezort M, Lohneis T, Zhang C. Multifunctional nanosystem for targeted and controlled delivery of multiple chemotherapeutic agents for the treatment of drug-resistant breast cancer. ACS Omega 2018;3:9210-9.

35. Zhou L, Wang H, Li Y. Stimuli-responsive nanomedicines for overcoming cancer multidrug resistance. Theranostics 2018;8:1059-74.

36. Qin SY, Cheng YJ, Lei Q, Zhang AQ, Zhang XZ. Combinational strategy for high-performance cancer chemotherapy. Biomaterials 2018;171:178-97.

37. Chen M, Liang X, Gao C, Zhao R, Zhang N, et al. Ultrasound triggered conversion of porphyrin/camptothecin-fluoroxyuridine triad 
microbubbles into nanoparticles overcomes multidrug resistance in colorectal cancer. ACS Nano 2018;12:7312-26.

38. Blanco E, Shen H, Ferrari M. Principles of nanoparticle design for overcoming biological barriers to drug delivery. Nat Biotechnol 2015;33:941-51.

39. Mu X, Li J, Yan S, Zhang H, Zhang W, et al. SiRNA Delivery with stem cell membrane-coated magnetic nanoparticles for imagingguided photothermal therapy and gene therapy. ACS Biomater Sci Eng 2018;4:3895-905.

40. Cheng G, Li W, Ha L, Han X, Hao S, et al. Self-Assembly of Extracellular Vesicle-like Metal-Organic Framework Nanoparticles for Protection and Intracellular Delivery of Biofunctional Proteins. J Am Chem Soc 2018;140:7282-91.

41. He H, Guo C, Wang J, Korzun WJ, Wang XY, et al. Leutusome: A Biomimetic Nanoplatform Integrating Plasma Membrane Components of Leukocytes and Tumor Cells for Remarkably Enhanced Solid Tumor Homing. Nano Lett 2018;18:6164-74.

42. Anchordoquy TJ, Barenholz Y, Boraschi D, Chorny M, Decuzzi P, et al. Mechanisms and barriers in cancer nanomedicine: addressing challenges, looking for solutions. ACS Nano 2017;11:12-8.

43. Mülhopt S, Diabaté S, Dilger M, Adelhelm C, Anderlohr C, et al. Characterization of nanoparticle batch-to-batch variability. Nanomaterials 2018;8:311.

44. Wilhelm S, Tavares AJ, Dai Q, Ohta S, Audet J, et al. Analysis of nanoparticle delivery to tumours. Nat Rev Mater 2016;1:16014.

45. Zhang YN, Poon W, Tavares AJ, McGilvray ID, Chan WCW. Nanoparticle-liver interactions: cellular uptake and hepatobiliary elimination. J Control Release 2016;240:332-48.

46. Rasmussen K, Rauscher H, Mech A, Riego Sintes J, Gilliland D, et al. Physico-chemical properties of manufactured nanomaterials characterisation and relevant methods. An outlook based on the OECD Testing Programme. Regul Toxicol Pharmacol 2018;92:8-28.

47. Hoter A, El-Sabban ME, Naim HY. The HSP90 family: structure, regulation, function, and implications in health and disease. Int J Mol Sci 2018;19:2560.

48. Schopf FH, Biebl MM, Buchner J. The HSP90 chaperone machinery. Nat Rev Mol Cell Biol 2017;18:345-60.

49. Prodromou C. Mechanisms of Hsp90 regulation. Biochem J 2016;473:2439-52.

50. Canonici A, Qadir Z, Conlon NT, Collins DM, O’Brien NA, et al. The HSP90 inhibitor NVP-AUY922 inhibits growth of HER2 positive and trastuzumab-resistant breast cancer cells. Invest New Drugs 2018;36:581-9.

51. Zhang G, Zhang H, Liu Y, He Y, Wang W, et al. CD44 clustering is involved in monocyte differentiation. Acta Biochim Biophys Sin (Shanghai) 2014;46:540-7.

52. Mellatyar H, Talaei S, Pilehvar-Soltanahmadi Y, Barzegar A, Akbarzadeh A, et al. Targeted cancer therapy through 17-DMAG as an Hsp90 inhibitor: overview and current state of the art. Biomed Pharmacother 2018;102:608-17.

53. Wang Y, McAlpine SR. N-terminal and C-terminal modulation of Hsp90 produce dissimilar phenotypes. Chem Commun (Camb) 2015;51:1410-3.

54. Wang X, Chen M, Zhou J, Zhang X. HSP27, 70 and 90, anti-apoptotic proteins, in clinical cancer therapy (review). Int J Oncol 2014;45:1830 .

55. Koay YC, McConnell JR, Wang Y, Kim SJ, Buckton LK, et al. Chemically accessible hsp90 inhibitor that does not induce a heat shock response. ACS Med Chem Lett 2014;5:771-6.

56. Audisio D, Methy-Gonnot D, Radanyi C, Renoir JM, Denis S, et al. Synthesis and antiproliferative activity of novobiocin analogues as potential hsp90 inhibitors. Eur J Med Chem 2014;83:498-507.

57. Radanyi C, Le Bras G, Messaoudi S, Bouclier C, Peyrat JF, et al. Synthesis and biological activity of simplified denoviose-coumarins related to novobiocin as potent inhibitors of heat-shock protein 90 (hsp90). Bioorg Med Chem Lett 2008;18:2495-8.

58. Audisio D, Messaoudi S, Cegielkowski L, Peyrat JF, Brion JD, et al. Discovery and biological activity of $6 \mathrm{BrCaQ}$ as an inhibitor of the Hsp90 protein folding machinery. ChemMedChem 2011;6:804-15.

59. Radanyi C, Le Bras G, Marsaud V, Peyrat JF, Messaoudi S, et al. Antiproliferative and apoptotic activities of tosylcyclonovobiocic acids as potent heat shock protein 90 inhibitors in human cancer cells. Cancer Lett 2009;274:88-94.

60. Donnelly A, Blagg BSJ. Novobiocin and additional inhibitors of the Hsp90 C-terminal nucleotide-binding pocket. Curr Med Chem 2008;15:2702-17.

61. Shelton SN, Shawgo ME, Matthews SB, Lu Y, Donnelly AC, et al. KU135, a novel novobiocin-derived C-terminal inhibitor of the 90$\mathrm{kDa}$ heat shock protein, exerts potent antiproliferative effects in human leukemic cells. Mol Pharmacol 2009;76: 1314-22.

62. Terracciano S, Russo A, Chini MG, Vaccaro MC, Potenza M, et al. Discovery of new molecular entities able to strongly interfere with Hsp90 C-terminal domain. Sci Rep 2018;8:1709.

63. Zhang FZ, Ho DHH, Wong RHF. Triptolide, a HSP90 middle domain inhibitor, induces apoptosis in triple manner. Oncotarget 2018;9:22301-15.

64. Bhatia S, Diedrich D, Frieg B, Ahlert H, Stein S, et al. Targeting HSP90 dimerization via the C terminus is effective in imatinib-resistant CML and lacks the heat shock response. Blood 2018;132:307-20.

65. Hyun SY, Le HT, Nguyen CT, Yong YS, Boo HJ, et al. Development of a novel Hsp90 inhibitor NCT-50 as a potential anticancer agent for the treatment of non-small cell lung cancer. Sci Rep 2018;8:13924.

66. Sidera K, Patsavoudi E. HSP90 inhibitors: current development and potential in cancer therapy. Recent Pat Anticancer Drug Discov 2014;9:1-20.

67. Solárová Z, Mojžiš J, Solár P. Hsp90 inhibitor as a sensitizer of cancer cells to different therapies (review). Int J Oncol 2015;46:907-26.

68. Ernst JT, Neubert T, Liu M, Sperry S, Zuccola H, et al. Identification of novel HSP $90 \alpha / \beta$ isoform selective inhibitors using structurebased drug design. demonstration of potential utility in treating CNS disorders such as huntington's disease. J Med Chem 2014;57:3382400 . 
69. Zou M, Bhatia A, Dong H, Jayaprakash P, Guo J, et al. Evolutionarily conserved dual lysine motif determines the non-chaperone function of secreted Hsp90alpha in tumour progression. Oncogene 2017;36:2160-71.

70. Yoshida S, Tsutsumi S, Muhlebach G, Sourbier C, Lee MJ, et al. Molecular chaperone TRAP1 regulates a metabolic switch between mitochondrial respiration and aerobic glycolysis. Proc Natl Acad Sci 2013:110:E1604-12.

71. Randow F, Seed B. Endoplasmic reticulum chaperone gp96 is required for innate immunity but not cell viability. Nat Cell Biol 2001;3:891-6.

72. Lee AS. Glucose-regulated proteins in cancer: molecular mechanisms and therapeutic potential. Nat Rev Cancer 2014;14:263-76.

73. Immormino RM, Metzger LE 4th, Reardon PN, Dollins DE, Blagg BS, et al. Different poses for ligand and chaperone in inhibitor-bound Hsp90 and GRP94: implications for paralog-specific drug design. J Mol Biol 2009;388:1033-42.

74. Muth A, Crowley V, Khandelwal A, Mishra S, Zhao J, et al. Development of radamide analogs as Grp94 inhibitors. Bioorganic Med Chem 2014;22:4083-98.

75. Patel HJ, Patel PD, Ochiana SO, Yan P, Sun W, et al. Structure-activity relationship in a purine-scaffold compound series with selectivity for the endoplasmic reticulum Hsp90 paralog Grp94. J Med Chem 2015;58:3922-43.

76. Mishra SJ, Ghosh S, Stothert AR, Dickey CA, Blagg BS. Transformation of the non-selective aminocyclohexanol-based Hsp 90 inhibitor into a Grp94-seletive scaffold. ACS Chem Biol 2017;12:244-53.

77. Khandelwal A, Crowley VM, Blagg BSJ. Resorcinol-Based Grp94-Selective Inhibitors. ACS Med Chem Lett 2017;8:1013-8.

78. Crowley VM, Huard DJE, Lieberman RL, Blagg BSJ. Second generation Grp94-selective inhibitors provide opportunities for the inhibition of metastatic cancer. Chem - A Eur J 2017;23:15775-82.

79. Stothert AR, Suntharalingam A, Tang X, Crowley VM, Mishra SJ, et al. Isoform-selective Hsp90 inhibition rescues model of hereditary open-angle glaucoma. Sci Rep 2017;7:17951.

80. Costantino E, Maddalena F, Calise S, Piscazzi A, Tirino V, et al. TRAP1, a novel mitochondrial chaperone responsible for multi-drug resistance and protection from apoptotis in human colorectal carcinoma cells. Cancer Lett 2009;279:39-46.

81. Palladino G, Notarangelo T, Pannone G, Piscazzi A, Lamacchia O, et al. TRAP1 regulates cell cycle and apoptosis in thyroid carcinoma cells. Endocr Relat Cancer 2016;23:699-709.

82. Agorreta J, Hu J, Liu D, Delia D, Turley H, et al. Cell cycle and senescence TRAP1 regulates proliferation, mitochondrial function, and has prognostic significance in NSCLC. Mol Cancer Res 2014;12:660-9.

83. Masgras I, Sanchez-Martin C, Colombo G, Rasola A. The chaperone TRAP1 as a modulator of the mitochondrial adaptations in cancer cells. Front Oncol 2017;7:58.

84. Landriscina M, Laudiero G, Maddalena F, Amoroso MR, Piscazzi A, et al. Mitochondrial chaperone trap1 and the calcium binding protein sorcin interact and protect cells against apoptosis induced by antiblastic agents. Cancer Res 2010;70:6577-86.

85. Park HK, Jeong H, Ko E, Lee G, Lee JE, et al. Paralog specificity determines subcellular distribution, action mechanism, and anticancer activity of TRAP1 inhibitors. J Med Chem 2017;60:7569-78.

86. Plescia J, Salz W, Xia F, Pennati M, Zaffaroni N, et al. Rational design of shepherdin, a novel anticancer agent. Cancer Cell 2005;7:45768.

87. Kang BH, Plescia J, Song HY, Meli M, Colombo G, et al. Combinatorial drug design targeting multiple cancer signaling networks controlled by mitochondrial Hsp90. J Clin Invest 2009;119:454-64.

88. Zielonka J, Joseph J, Sikora A, Hardy M, Ouari O, et al. Mitochondria-targeted triphenylphosphonium-based compounds: syntheses, mechanisms of action, and therapeutic and diagnostic applications. Chem Rev 2017;117:10043-120.

89. Rondanin R, Lettini G, Oliva P, Baruchello R, Costantini C, et al. New TRAP1 and Hsp90 chaperone inhibitors with cationic components: preliminary studies on mitochondrial targeting. Bioorganic Med Chem Lett 2018;28:2289-93.

90. Yoo SH, Kim HY, Rho JH, Jeong SY, Yun J, et al. Targeted inhibition of mitochondrial Hsp90 induces mitochondrial elongation in Hep3B hepatocellular carcinoma cells undergoing apoptosis by increasing the ROS level. Int J Oncol 2015;47:1783-92.

91. Yan C, Oh JS, Yoo SH, Lee JS, Yoon YG, et al. The targeted inhibition of mitochondrial Hsp90 overcomes the apoptosis resistance conferred by Bcl-2 in Hep3B cells via necroptosis. Toxicol Appl Pharmacol 2013;266:9-18.

92. Ishida CT, Canoll P, Bruce JN, Roth KA, Siegelin MD, et al. Inhibition of mitochondrial matrix chaperones and antiapoptotic Bcl-2 family proteins empower antitumor therapeutic responses. Cancer Res 2017;77:3513-26.

93. Kang BH, Siegelin MD, Plescia J, Raskett CM, Garlick DS, et al. Preclinical characterization of mitochondria-targeted small molecule hsp90 inhibitors, gamitrinibs, in advanced prostate cancer. Clin Cancer Res 2010;16:4779-88.

94. Hou XS, Wang HS, Mugaka BP, Yang GJ, Ding Y. Mitochondria: promising organelle targets for cancer diagnosis and treatment. Biomater Sci 2018;6:2786-97.

95. Amoroso MR, Matassa DS, Agliarulo I, Avolio R, Maddalena F, et al. Stress-adaptive response in ovarian cancer drug resistance: role of TRAP1 in oxidative metabolism-driven inflammation. Adv Protein Chem Struct Biol 2017;108:163-98.

96. Sciacovelli M, Guzzo G, Morello V, Frezza C, Zheng L, et al. The mitochondrial chaperone TRAP1 promotes neoplastic growth by inhibiting succinate dehydrogenase. Cell Metab 2013;17:988-99.

97. Matassa DS, Agliarulo I, Avolio R, Landriscina M, Esposito F. Trap1 regulation of cancer metabolism: dual role as oncogene or tumor suppressor. Genes (Basel) 2018;9:195.

98. Maddalena F, Sisinni L, Lettini G, Condelli V, Matassa DS, et al. Resistance to paclitxel in breast carcinoma cells requires a quality control of mitochondrial antiapoptotic proteins by TRAP1. Mol Oncol 2013;7:895-906.

99. Calero R, Morchon E, Martinez-Argudo I, Serrano R. Synergistic anti-tumor effect of 17AAG with the PI3K/mTOR inhibitor NVPBEZ235 on human melanoma. Cancer Lett 2017;406:1-11. 
100. Wang H, Sun M, Guo J, Ma L, Jiang H, et al. 3-O-(Z)-coumaroyloleanolic acid overcomes Ckslb-induced chemoresistance in lung cancer by inhibiting Hsp90 and MEK pathways. Biochem Pharmacol 2017;135:35-49.

101. McLaughlin M, Barker HE, Khan AA, Pedersen M, Dillon M, et al. HSP90 inhibition sensitizes head and neck cancer to platin-based chemoradiotherapy by modulation of the DNA damage response resulting in chromosomal fragmentation. BMC Cancer 2017;17:86.

102. Jacobson C, Kopp N, Layer JV, Redd RA, Tschuri S, et al. HSP90 inhibition overcomes ibrutinib resistance in mantle cell lymphoma. Blood 2016;128:2517-26.

103. Park KS, Yang H, Choi J, Seo S, Kim D, et al. The HSP90 inhibitor, NVP-AUY922, attenuates intrinsic PI3K inhibitor resistance in KRAS-mutant non-small cell lung cancer. Cancer Lett 2017;406:47-53.

104. Park KS, Oh B, Lee MH, Nam KY, Jin HR, et al. The HSP90 inhibitor, NVP-AUY922, sensitizes KRAS-mutant non-small cell lung cancer with intrinsic resistance to MEK inhibitor, trametinib. Cancer Lett 2016;372:75-81.

105. Bai J, Zhou G, Qiu Y, Hu Y, Liu J, et al. HSP90 inhibitor AUY922 can reverse Fulvestrant induced feedback reaction in human breast cancer cells. Cancer Sci 2017;108:1177-84.

106. Geng K, Liu H, Song Z, Zhang C, Zhang M, et al. Design, synthesis and pharmacological evaluation of ALK and Hsp90 dual inhibitors bearing resorcinol and 2,4-diaminopyrimidine motifs. Eur J Med Chem 2018;152:76-86.

107. Jiang J, Lu Y, Li Z, Li L, Niu D, et al. Ganetespib overcomes resistance to PARP inhibitors in breast cancer by targeting core proteins in the DNA repair machinery. Invest New Drugs 2017;35:251-9.

108. Huang L, Wei G, Sun X, Jiang Y, Huang Z, et al. A tumor-targeted Ganetespib-zinc phthalocyanine conjugate for synergistic chemophotodynamic therapy. Eur J Med Chem 2018;151:294-303.

109. Jhaveri K, Wang R, Teplinsky E, Chandarlapaty S, Solit D, et al. A phase I trial of ganetespib in combination with paclitaxel and trastuzumab in patients with human epidermal growth factor receptor-2 (HER2)-positive metastatic breast cancer. Breast Cancer Res 2017;19:89.

110. Cavenagh J, Oakervee H, Baetiong-Caguioa P, Davies F, Gharibo M, et al. A phase I/II study of KW-2478, an Hsp90 inhibitor, in combination with bortezomib in patients with relapsed/refractory multiple myeloma. Br J Cancer 2017;117:1295-302.

111. Sauvage F, Messaoudi S, Fattal E, Barratt G, Vergnaud-Gauduchon J. Heat shock proteins and cancer: how can nanomedicine be harnessed? J Control Release 2017;248:133-43.

112. Le B, Powers GL, Tam YT, Schumacher N, Malinowski RL, et al. Multi-drug loaded micelles delivering chemotherapy and targeted therapies directed against HSP90 and the PI3K/AKT/ mTOR pathway in prostate cancer. PLoS One 2017;12:e0174658.

113. Shin DH, Kwon GS. Pre-clinical evaluation of a themosensitive gel containing epothilone B and mTOR/Hsp90 targeted agents in an ovarian tumor model. J Control Release 2017;268:176-83.

114. Peng CL, Shieh MJ, Lee PC, Liu HJ, Chen YI, et al. A novel temperature-responsive micelle for enhancing combination therapy. Int J Nanomedicine 2016;11:3357-69.

115. Long Q, Lin TY, Huang Y, Li X, Ma AH, et al. Image-guided photo-therapeutic nanoporphyrin synergized HSP90 inhibitor in patientderived xenograft bladder cancer model. Nanomedicine 2018;14:789-99.

116. Sauvage F, Fattal E, Al-Shaer W, Denis S, Brotin E, et al. Antitumor activity of nanoliposomes encapsulating the novobiocin analog 6BrCaQ in a triple-negative breast cancer model in mice. Cancer Lett 2018;432:103-11.

117. Sauvage F, Franzè S, Bruneau A, Alami M, Denis S, et al. Formulation and in vitro efficacy of liposomes containing the Hsp 90 inhibitor 6BrCaQ in prostate cancer cells. Int J Pharm 2016;499:101-9.

118. Rahimi MN, Foster H, Farazi S, Chapman R, McAlpine SR. Polymer mediated transport of the Hsp90 inhibitor LB76, a polar cyclic peptide, produces an Hsp90 cellular phenotype. Chem Commun (Camb) 2019;55:4515-8.

119. Mondal SK, Jinka S, Pal K, Nelli S, Dutta SK, et al. Glucocorticoid receptor-targeted liposomal codelivery of lipophilic drug and antiHsp90 gene: strategy to induce drug-sensitivity, EMT-reversal, and reduced malignancy in aggressive tumors. Mol Pharm 2016;13:250723.

120. Pore SK, Choudhary A, Rathore B, Ganguly A, Sujitha P, et al. Hsp90-targeted miRNA-liposomal formulation for systemic antitumor effect. Biomaterials 2013;34:6804-17.

121. Mitra K, Samsó M, Lyons CE, Hartman MCT. Hyaluronic acid grafted nanoparticles of a platinum(ii)-silicon(iv) phthalocyanine conjugate for tumor and mitochondria-targeted photodynamic therapy in red light. J Mater Chem B 2018;6:7373-7.

122. Wang K, Qi M, Guo C, Yu Y, Wang B, et al. Novel dual mitochondrial and CD44 receptor targeting nanoparticles for redox stimulitriggered release. Nanoscale Res Lett 2018;13:32.

123. Thomas AP, Palanikumar L, Jeena MT, Kim K, Ryu JH. Cancer-mitochondria-targeted photodynamic therapy with supramolecular assembly of HA and a water soluble NIR cyanine dye. Chem Sci 2017;8:8351-6.

124. Wei G, Wang Y, Huang X, Yang G, Zhao J, et al. Induction of mitochondrial apoptosis for cancer therapy: Via dual-targeted cascaderesponsive multifunctional micelles. J Mater Chem B 2018;6:8137-47. 